\title{
Antimicrobial activity of selected indigenous medicinal herbs against human pathogenic bacteria
}

Fahmeeda Rehman ${ }^{1}$, Ashif Sajjad ${ }^{1}$, Muhammad Aslam Mengal ${ }^{2}$, Muhammad Kamran Taj ${ }^{3 *}$, Mohammad Alam Mengal ${ }^{3}$, Muhammad Hashim Mengal ${ }^{4}$ and Saima Azam ${ }^{3}$

1. Institute of Biochemistry, University of Balochistan, Quetta-Pakistan

2. Bolan Medical College- Hospital Quetta, Balochistan-Pakistan

3. Center for Advanced Studies in Vaccinology and Biotechnology (CASVAB) University of Balochistan, Quetta-

Pakistan

4. World Health Organization Balochistan-Pakistan

*Corresponding author's email: kamrancasvab@yahoo.com

Citation

Fahmeeda Rehman, Ashif Sajjad, Muhammad Aslam Mengal, Muhammad Kamran Taj, Mohammad Alam Mengal, Muhammad Hashim Mengal and Saima Azam Antimicrobial activity of selected indigenous medicinal herbs against human pathogenic bacteria. Pure and Applied Biology. Vol. 6, Issue 2, pp740-747.

http://dx.doi.org/10.19045/bspab.2017.60079

Received: 05/02/2016 Revised: 30/05/2017

Accepted: 06/06/2017

Online First: 12/06/2017

\section{Abstract}

The traditionally use of indigenous medicinal plants in the treatment of burn, dermatrophytes and human infectious diseases and also still essential part of primary public health care. Antimicrobial activities of nine medicinal plants were determined in vitro through agar well diffusion method against pathogenic microorganism species of gastrointestinal tract. Medicinal plants extract of Cocculus pendulus, Malva neglecta, Rhazya stricta, Jaubertia aucheri, Corchorus depressus, Salvia bucharica, Microcephala lamellate, Berberis baluchistanica and Artemisa absinthium were found sensitive to Clostridium spp. The extracts of Malva neglecta, Jaubertia aucheri, Salvia bucharica and Berberis baluchistanica were observed sensitive to E. coli. Similarly the extracts of Malva neglecta, Jaubertia aucheri, Rhazya stricta, Corchorus depressus, and Artemisa absinthium were found sensitive to Salmonella spp. The extracts of Cocculus pendulus, Malva neglecta, Jaubertia aucheri, Corchorus depressus, Salvia bucharica, Microcephala lamellate, Berberis baluchistanica and Artemisa absinthium were sensitive to Shigella spp. The extracts of Cocculus pendulus, Jaubertia aucheri and Berberis baluchistanica were found sensitive to Klebsiella spp. The extracts of Cocculus pendulus, Rhazya stricta, Corchorus depressus, Microcephala lamellate and Artemisa absinthium were revealed resistance to E. coli. The extracts of Cocculus pendulus, Salvia bucharica, Microcephala lamellate and Berberis baluchistanica were revealed resistance to Salmonella spp. The extract of Rhazya stricta was revealed resistance to Shigella spp. The extracts of Malva neglecta, Rhazya stricta, Corchorus depressus, Salvia bucharica, Microcephala lamellate and Artemisa absinthium were revealed to resistance to Klebsiella spp. The extract of Jaubertia aucheri was highly sensitivity against E. coli, Salmonella spp, Shigella spp, Clostridium spp and Klebsiella spp.

Keywords: Plants; Herbs, Bacteria; Gastrointestinal; Balochistan 


\section{Introduction}

The herb meaning is grass which derived from the Latin word "herba", and primarily it was applied to a wide range of leafy vegetables. Herbs are seed plants that do not produce woody stems like a tree and live long enough to develop and produce flowers and seeds [1]. Many decades herbs have been used for their flavor, medicinal, antimicrobial and anti-oxidative properties. The most important part of herbs are considered as powerful tools to establish wellness such as stimulate production of enzymes that detoxify carcinogens, inhibit cholesterol synthesis, block estrogen, lower blood pressure and prevent blood clotting [2]. In addition herb plants providing nutrition and have an important source of chemical compounds, which could be used for medicinal purposes by human. According to the ancient human knowledge the importance of medicinal plants are date back to many centuries ago [3].

However, medicinal plants have been used as traditional medicine with excellent efficacious remedies and serve as dietary source to animals and humans. The plants provide sufficient nutrients to meet the metabolic requirements for their health, growth and productivity and also play essential role reducing the risk or delaying the onset of diseases and disorders [4], [5]. The world's population approximately $80 \%$ relies on traditional medicine for their primary health care. [6]. A various plants are being used as medicinal agents all over the world. It has been reported that many species possess medicinal use such as 1500 species in India [7], 5000 species in china [8] and 1600 species in north-west Amazonia [9]. Similarly it is noted that plants based medicine as a potential more effective limit the diseases and cheaper, therefore probably herbal medicines are responsible for the fast growing industry [10]. Currently traditional use of plants by indigenous communities many drugs in the market have come from folk medicine [11]. Moreover, medicinal plants played key roles in the health care for human and livestock. Therefore plants extracts and natural compounds are used controlling diverse diseases such as cough, inflammation and diarrhea in human and livestock. A large number of medicinal plants have been screened and validated for their ethnopharmacological [12].

Pakistan has diverse weather condition and great biodiversity of medicinal plants. Generally medicinal plants are produced in large quantities in the mountainous area than in grasslands due to obviously favorable habitat and suitable climatic conditions [13]. Balochistan province is also natural homeproducer of many medicinal plants and soled in native market place [14]. In Pakistan medicinal plants are naturally grown in ecological zones and rich flora of over 6000 plant species and more than 1000 species are identified as medicinal and aromatic plant species and also small scale of some species are cultivated. Temperature fluctuates below zero in the Northern mountainous area and $50{ }^{0} \mathrm{C}$ in the Southern plains in Pakistan. The usage of medicinal plants improved knowingly to abilities for healing purpose [15]. The demand of medicinal plants is increasing both in developed and developing countries and like Pakistan people depends on medicinal plants for health care, food, shelter and fodder for animals which plays a vital role against different bacterial infections [16].

There are definitely abundant clinical studies have not been reported for antimicrobial activity of local plants against pathogenic bacteria in Balochistan province. Hence, the present study attempt to determine the antimicrobial activity of local herbal medicinal plants against pathogenic bacteria such as Salmonella spp, E. coli, 
Shigella spp, Klebsiella spp and Clostridium spp.

\section{Materials and methods}

\section{Collection of plant samples}

Nine medicinal plants species (Cocculus pendulus, Malva neglecta, Jaubertia aucheri, Rhazya stricta, Corchorus depressus, Salvia bucharica, Microcephala lamellate, Berberis baluchistanica and Artemisa absinthium) were obtained from different locations of Balochistan, Pakistan. Plants were washed with tap water in order to remove the dust and identified by a qualified plant taxonomist and labeled kept in the Center for Advanced Studies in Vaccinology and Biotechnology" (CASVAB) University of Balochistan and "Institute of Biochemistry" University of Balochistan, Quetta for extraction and further analysis.

\section{Preparation of plants extract}

The plant samples were dried and grind into fine powder by using a blender (ANEXAG-179 GL). The samples were soaked in $50 \mathrm{ml}$ methanol (LAB-SCAN ASIA Co., LTD) and shake twice a day, placed for two weeks at room temperature $\left(25^{\circ} \mathrm{C}\right)$. After two weeks, the mixture was twice filtered by Watt-man No-14 filter paper (Watt-man Grade 14), than methanol was completely evaporated by the help of rotary evaporator (Buchi Rotary - evaporator Model R-205). The obtained semisolid extracts were kept (open air) for two days and the extracts were stored at $8^{0} \mathrm{C}$ for the further analysis [17].

\section{Pathogenic microorganisms}

The human pathogenic microorganisms such as E. coli, Salmonella spp, Shigella spp, Clostridium spp and Klebsiella spp were used for antibacterial activity. The bacteria were purified and biochemically characterized through different selective media (MacConkey Reinforced Clostridium and Salmonella- Shigella agar media), and tests (Indole, MR-VP and Sugar fermentation tests). The entire tests were performed three times at $37{ }^{0} \mathrm{C}$ and were incubated according to bacteria.

\section{Preparation of medium}

Brain heart infusion broth and agar (1.5\%) were prepared by using distilled water for the growth of bacteria and $\mathrm{pH}$ of the medium was adjusted at $7.0 \mathrm{pH}$. The dissolved medium was autoclaved at $15 \mathrm{lbs}$ pressure at $121^{\circ} \mathrm{C}$ for 15 minutes. Three times experiments were performed to the confirmation of the sensitivity and resistance on herbal extracts for bacterial growth.

\section{Agar well diffusion method}

Agar diffusion method was used to determine the antimicrobial activity of medicinal plants. The $6 \mathrm{~mm}$ holes were made in agar plate and $50 \mathrm{ul}$ extract solution was poured in it. After $24 \mathrm{hrs}$ the zone of inhibition was recorded.

\section{Results}

The antimicrobial activity of methanol extracts of 9 (nine) indigenous medicinal herbs were investigated by using agar well diffusion method against human pathogenic bacteria such as E. coli, Salmonella spp, Shigella spp, Clostridium spp and Klebsiella spp.

In the agar well diffusion method the Cocculus pendulus extract showed maximum zone of inhibition against Clostridium spp, Klebsiella spp, Shigella spp while E. coli and Salmonella spp were resistance to Cocculus pendulus extract as shown in Table 1.

Table 1. Zone of inhibition on Cocculus pendulus extract against pathogenic bacteria

\begin{tabular}{|l|l|l|l|l|l|l|}
\hline $\begin{array}{l}\text { Botanical } \\
\text { Name }\end{array}$ & $\begin{array}{l}\text { Common } \\
\text { Name }\end{array}$ & E. coli & $\begin{array}{l}\text { Salmonella } \\
\text { spp }\end{array}$ & $\begin{array}{l}\text { Shigella } \\
\text { spp }\end{array}$ & $\begin{array}{l}\text { Clostridium } \\
\text { spp }\end{array}$ & $\begin{array}{l}\text { Klebsiella } \\
\text { spp }\end{array}$ \\
\hline $\begin{array}{l}\text { Cocculus } \\
\text { pendulus }\end{array}$ & Zamur & - & - & $17 \mathrm{~mm}$ & $26 \mathrm{~mm}$ & $20 \mathrm{~mm}$ \\
\hline
\end{tabular}


The Malva neglecta extracts showed maximum zone of inhibition against Shigella spp, E. coli, Clostridium spp, and

Salmonella spp while Klebsiella spp was resistance to Malva neglecta extracts shown in Table 2.

Table 2. Zone of inhibition on the Malva neglecta extract against pathogenic bacteria

\begin{tabular}{|l|l|l|l|l|l|l|}
\hline $\begin{array}{l}\text { Botanical } \\
\text { Name }\end{array}$ & $\begin{array}{l}\text { Common } \\
\text { Name }\end{array}$ & E. coli & $\begin{array}{l}\text { Salmonella } \\
\text { spp }\end{array}$ & $\begin{array}{l}\text { Shigella } \\
\text { spp }\end{array}$ & $\begin{array}{l}\text { Clostridium } \\
\text { spp }\end{array}$ & $\begin{array}{l}\text { Klebsiella } \\
\text { spp }\end{array}$ \\
\hline $\begin{array}{l}\text { Malva } \\
\text { neglecta }\end{array}$ & Pochko & $21 \mathrm{~mm}$ & $14 \mathrm{~mm}$ & $31 \mathrm{~mm}$ & $16 \mathrm{~mm}$ & - \\
\hline
\end{tabular}

The Jaubertia aucheri extract showed maximum zone of inhibition against Clostridium spp, E. coli, Salmonella spp and
Klebsiella spp while Shigella spp was minimum Jaubertia aucheri extract as shown in Table 3.

Table 3. Zone of inhibition on the Jaubertia aucheri extract against pathogenic bacteria

\begin{tabular}{|l|l|l|l|l|l|l|}
\hline $\begin{array}{l}\text { Botanical } \\
\text { Name }\end{array}$ & $\begin{array}{l}\text { Common } \\
\text { Name }\end{array}$ & E. coli & $\begin{array}{l}\text { Salmonella } \\
\text { spp }\end{array}$ & $\begin{array}{l}\text { Shigella } \\
\text { spp }\end{array}$ & $\begin{array}{l}\text { Clostridium } \\
\text { spp }\end{array}$ & $\begin{array}{l}\text { Klebsiella } \\
\text { spp }\end{array}$ \\
\hline $\begin{array}{l}\text { Jaubertia } \\
\text { aucheri }\end{array}$ & Thusso & $24 \mathrm{~mm}$ & $22 \mathrm{~mm}$ & $19 \mathrm{~mm}$ & $26 \mathrm{~mm}$ & $20 \mathrm{~mm}$ \\
\hline
\end{tabular}

The Rhazya stricta extract showed maximum zone of inhibition against Clostridium spp, Salmonella spp while
Klebsiella spp, Shigella spp and E. coli were resistance to Rhazya stricta extract as shown in Table 4.

Table 4. Zone of inhibition on the Rhazya stricta extract against pathogenic bacteria

\begin{tabular}{|l|l|l|l|l|l|l|}
\hline $\begin{array}{l}\text { Botanical } \\
\text { Name }\end{array}$ & $\begin{array}{l}\text { Common } \\
\text { Name }\end{array}$ & E. coli & $\begin{array}{l}\text { Salmonella } \\
\text { spp }\end{array}$ & $\begin{array}{l}\text { Shigella } \\
\text { spp }\end{array}$ & $\begin{array}{l}\text { Clostridium } \\
\text { spp }\end{array}$ & $\begin{array}{l}\text { Klebsiella } \\
\text { spp }\end{array}$ \\
\hline $\begin{array}{l}\text { Rhazya } \\
\text { stricta }\end{array}$ & Aeshark & - & $24 \mathrm{~mm}$ & - & $31 \mathrm{~mm}$ & - \\
\hline
\end{tabular}

The Corchorus depressus extract showed maximum zone of inhibition against Clostridium spp, Shigella spp, Salmonella spp, Klebsiella spp while E. coli was resistance to Corchorus depressus extract as shown in Table 5.

Table 5. Zone of inhibition on the Corchorus depressus extract against pathogenic bacteria

\begin{tabular}{|l|l|l|l|l|l|l|}
\hline $\begin{array}{l}\text { Botanical } \\
\text { Name }\end{array}$ & $\begin{array}{l}\text { Common } \\
\text { Name }\end{array}$ & E. coli & $\begin{array}{l}\text { Salmonella } \\
\text { spp }\end{array}$ & $\begin{array}{l}\text { Shigella } \\
\text { spp }\end{array}$ & $\begin{array}{l}\text { Clostridium } \\
\text { spp }\end{array}$ & $\begin{array}{l}\text { Klebsiella } \\
\text { spp }\end{array}$ \\
\hline $\begin{array}{l}\text { Corchorus } \\
\text { depressus }\end{array}$ & Bandary & - & $16 \mathrm{~mm}$ & $17 \mathrm{~mm}$ & $22 \mathrm{~mm}$ & - \\
\hline
\end{tabular}

The Salvia bucharica extracts showed maximum zone of inhibition against Clostridium spp, E. coli, Shigella spp while Salmonella spp and Klebsiella spp were resistance to Salvia bucharica extract as shown in Table 6. 
Table 6. Zone of inhibition on the Salvia bucharica extract against pathogenic bacteria

\begin{tabular}{|l|l|l|l|l|l|l|}
\hline $\begin{array}{l}\text { Botanical } \\
\text { Name }\end{array}$ & $\begin{array}{l}\text { Common } \\
\text { Name }\end{array}$ & E. coli & $\begin{array}{l}\text { Salmonella } \\
\text { spp }\end{array}$ & $\begin{array}{l}\text { Shigella } \\
\text { spp }\end{array}$ & $\begin{array}{l}\text { Clostridium } \\
\text { spp }\end{array}$ & $\begin{array}{l}\text { Klebsiella } \\
\text { spp }\end{array}$ \\
\hline $\begin{array}{l}\text { Salvia } \\
\text { bucharica }\end{array}$ & $\begin{array}{l}\text { Gul-e- } \\
\text { kakar }\end{array}$ & $21 \mathrm{~mm}$ & - & $16 \mathrm{~mm}$ & $31 \mathrm{~mm}$ & - \\
\hline
\end{tabular}

The Microcephala lamellate extract showed maximum zone of inhibition against Clostridium spp, Shigella spp while
Salmonella spp, E. coli and Klebsiella spp were resistance to Microcephala lamellate extract as shown in Table 7.

Table 7. Zone of inhibition on the Microcephala lamellate extract against pathogenic bacteria

\begin{tabular}{|l|l|l|l|l|l|l|}
\hline $\begin{array}{l}\text { Botanical } \\
\text { Name }\end{array}$ & $\begin{array}{l}\text { Common } \\
\text { Name }\end{array}$ & E. coli & $\begin{array}{l}\text { Salmonella } \\
\text { spp }\end{array}$ & $\begin{array}{l}\text { Shigella } \\
\text { spp }\end{array}$ & $\begin{array}{l}\text { Clostridium } \\
\text { spp }\end{array}$ & $\begin{array}{l}\text { Klebsiella } \\
\text { spp }\end{array}$ \\
\hline $\begin{array}{l}\text { Microcephala } \\
\text { lamellate }\end{array}$ & Phenophulii & - & - & $16 \mathrm{~mm}$ & $26 \mathrm{~mm}$ & - \\
\hline
\end{tabular}

The Berberis baluchistanica extract showed maximum zone of inhibition against E. coli, Clostridium spp, Shigella spp and Klebsiella spp while Salmonella spp were resistance to Berberis baluchistanica extract as shown in Table 8 .

Table 8. Zone of inhibition on the Berberis baluchistanica extract against pathogenic bacteria

\begin{tabular}{|l|l|l|l|l|l|c|}
\hline $\begin{array}{l}\text { Botanical } \\
\text { Name }\end{array}$ & $\begin{array}{l}\text { Common } \\
\text { Name }\end{array}$ & E. coli & $\begin{array}{l}\text { Salmonella } \\
\text { spp }\end{array}$ & $\begin{array}{l}\text { Shigella } \\
\text { spp }\end{array}$ & $\begin{array}{l}\text { Clostridium } \\
\text { spp }\end{array}$ & $\begin{array}{l}\text { Klebsiella } \\
\text { spp }\end{array}$ \\
\hline $\begin{array}{l}\text { Berberis } \\
\text { baluchistanica }\end{array}$ & $\begin{array}{l}\text { Badrah / } \\
\text { Zarch }\end{array}$ & $19 \mathrm{~mm}$ & - & $15 \mathrm{~mm}$ & $16 \mathrm{~mm}$ & $16 \mathrm{~mm}$ \\
\hline
\end{tabular}

The Artemisa absinthium extracts showed maximum zone of inhibition against Salmonella spp, Clostridium spp, Shigella spp while E. coli and Klebsiella spp were resistance to Artemisa absinthium extract as shown in Table-9.

Table 9. Zone of inhibition on the Artemisa absinthium extract against pathogenic bacteria

\begin{tabular}{|l|l|l|l|l|l|l|}
\hline $\begin{array}{l}\text { Botanical } \\
\text { Name }\end{array}$ & $\begin{array}{l}\text { Common } \\
\text { Name }\end{array}$ & E. coli & $\begin{array}{l}\text { Salmonella } \\
\text { spp }\end{array}$ & $\begin{array}{l}\text { Shigella } \\
\text { spp }\end{array}$ & $\begin{array}{l}\text { Clostridium } \\
\text { spp }\end{array}$ & $\begin{array}{l}\text { Klebsiella } \\
\text { spp }\end{array}$ \\
\hline $\begin{array}{l}\text { Artemisa } \\
\text { absinthium }\end{array}$ & Aftasen & - & $26 \mathrm{~mm}$ & $14 \mathrm{~mm}$ & $21 \mathrm{~mm}$ & - \\
\hline
\end{tabular}

\section{Biochemical tests}

Different biochemical tests were performed for the confirmation of Gram negative and
Gram positive bacteria as shown in Table 10. 
Table 10. Biochemical test results for the gram positive bacteria and gram negative bacteria

\begin{tabular}{|l|l|l|c|l|c|c|}
\hline S.No & Biochemical test & E. coli & $\begin{array}{l}\text { Salmonella } \\
\text { spp }\end{array}$ & $\begin{array}{l}\text { Shigella } \\
\text { spp }\end{array}$ & $\begin{array}{l}\text { Klebsiella } \\
\text { spp }\end{array}$ & $\begin{array}{l}\text { Clostridium } \\
\text { spp }\end{array}$ \\
\hline 1- & Methyl red & + & + & + & - & - \\
\hline $2-$ & Indole test & + & - & variable & - & - \\
\hline $3-$ & Voges-proskauer & - & - & - & + & - \\
\hline $4-$ & Lactose & + & - & - & + & + \\
\hline $5-$ & Maltose & + & + & variable & + & + \\
\hline 6- & Mannitol & + & + & variable & + & - \\
\hline $7-$ & Sucrose & D & - & - & + & + \\
\hline
\end{tabular}

$\mathrm{d}=29-57 \%$ positive, $\mathrm{V}=$ reaction variable between species

\section{Discussion}

Medicinal plants comprise one of the major non wood forest practices and it has antimicrobial activity. The antimicrobial activities of methanol extracts of nine medicinal plants were determined in vitro through agar well diffusion method against pathogenic microorganism species and these caused different infection in human being. The antimicrobial activity result revealed that Jaubertia aucheri was highly sensitivity against E. coli, Salmonella spp, Shigella spp, Klebsiella spp and Clostridium spp. Microcephala lamellate showed sensitivity against Shigella spp and Clostridium spp while complete resistance towards the $E$. coli, Salmonella spp and Klebsiella spp. Malva neglecta showed sensitivity against E. coli, Salmonella spp, Shigella spp and Clostridium spp while show resistance towards the Klebsiella spp. The Cocculus pendulus have good medical values in traditional system and our results also showed that Cocculus pendulus was sensitivity against Shigella spp, Clostridium spp and Klebsiella spp while show resistance towards the $E$. coli and Salmonella spp. Rhazya stricta is used in various diseases and it have antimicrobial activity against Salmonella spp and Clostridium spp while show resistance towards the E. coli, Shigella spp and Klebsiella spp. Corchorus depressus showed sensitivity against Salmonella spp, Shigella spp and Clostridium spp while show resistance towards the E. coli and Klebsiella spp. Salvia bucharica showed sensitivity against E. coli, Shigella spp and Clostridium spp while show resistance towards the Salmonella spp and Klebsiella spp. Berberis baluchistanica showed sensitivity against E. coli, Shigella spp, Clostridium spp and Klebsiella spp while show resistance towards Salmonella spp. Artemisa absinthium showed sensitivity against Salmonella spp, Shigella spp and Clostridium spp while show resistance towards the E. coli and Klebsiella spp. The Gram positive bacteria were more sensitive than Gram negative bacteria. This can be due to the variance in their cell wall composition as same as described by [18]. Medicinal herbs are great significance used for different infectious diseases. Jaubertia aucher showed higher antimicrobial activity against Clostridium spp, E. coli, Salmonella spp, Shigella spp and Klebsiella spp. Pakistan is developing country and people of it have various diseases so it is necessary to search out good medicinal herb which will help for detection of active intergradient for the control of diseases. 


\section{Conclusion}

Many diseases are common in the third world countries. It is essential to search out and stimulate medicines that are plant based. This work will support to isolate active intergradient for the treatment of bacterial diseases.

\section{Authors' contributions}

Conceived and designed the experiments: $\mathrm{F}$ Rehman, A Sajjid \& MK Taj, Performed the Experiments: R Rehman, MK Taj, \& MA Mengal, Analyzed the Data: F Rehman, H Mengal, A Mengal \& S Azam, Contributed reagents/ materials/ analysis tools: $\mathrm{F}$ Rehman \& A Sajjid, Wrote the paper: F Rehman \& MK Taj

\section{Acknowledgements}

I would like to thank "Center for Advanced Studies in Vaccinology and Biotechnology (CASVAB) University of Balochistan" and "Institute of Biochemistry University of Balochistan, Quetta" for the technical and material support and facility of laboratory space for the extraction processes and equipment to carry out this research work for use of the microbiology laboratory.

\section{References}

1. Gerald J (1975). The herbal or general history of plants. $1633 \mathrm{Ed}$. Arco Pub Corporation; New York. 1-13 p.

2. Uhl S (2000). Spices: tools for alternative or complementary medicine. Food Technol 54(5): 61-65.

3. Rahmatullah M, Noman A, Hossan MS, Rashid M, Rahman T, Chowdhury MH \& Jahan R (2009). A survey of medicinal plants in two areas of Dinajpur district, Bangladesh including plants which can be used as functional foods. Amer Eur J of Sust Agri 3(4): 862-876.

4. Ghani A (2003). Medicinal plants of Bangladesh. $2^{\text {nd }}$ Ed. Asiatic society of Bangladesh; Dhaka, Bangladesh.

5. Kosar MB, Bozan B, Temelli F, \& Baser KHC (2007). Antioxidant activity and phenolic composition of sumac
(Rhuscoriaria L) extracts. Food chemistry 103(3): 952-959.

6. Behera KK (2006). Ethno-medicinal plants used by the tribals of similipal bioreserve. A Int J Ethano Resh 10(29): 149-173.

7. Kumar KNS (2015). Herbal Pharmacopoeias- an overview of international and Indian representation. $J$ Ayurvedic and Herbal Medi 1(3): 59-60

8. WHO (2003). Report of Traditional Medicine. World Health Organization, Geneva, WHO.

9. Rodrigues E, \& Carlini EA (2006). Plants with possible psychoactive effects used by the Krahô Indians, Brazil. Rev Bras Psiquiatr 28(4): 277-82

10. Rojas JJ, Ochoa VJ, Ocampo SA, \& Munoz JF (2006). Screening for antimicrobial activity of ten medicinal plants used in Colombian folkloric medicine: a possible alternative in the treatment of nanosocomial infections. BMC Complement Altern Med (6):2.

11. Cragg G \& Newman D (2013). Industrial applications and natural products for medicinal purposes. Natural products in the new millennium: Prosp and Indus Appli 47(4): 281-285.

12. Gutierrez SP, Sanchez MAZ, Gonzalez CP, \& Garcia LA (2007). Antidiarrheal activity of different plantsused in traditional medicine. African J Biotech 6(25): 2988-2994.

13. Sher H, Aldosari A, Ali A, \& Boer HJD (2014). Economic benefits of high value medicinal plants to Pakistani communities: an analysis of current practice and potential. $J$ Ethnobiol Ethnomed 10: 71.

14. Ahmed S, Koukab S, Islam M, Ahmed K, Aslam S, Aminullah GA, \& Gill A (2008). Germplasm evaluation of medicinal and aromatic plants in 
highland Balochistan, Pakistan. Pak J of Botany 40(4): 1473-1479.

15. Khan IA, Allgood J, Walker LA, Abourashed EA, Schelenk D, \& Benson WH (2001). Determination of heavy metals and pesticides in ginseng products. J Asso of Agri Chemist Inter 84(3):936-9.

16. Shinwari ZK (2010). Medicinal plants research in Pakistan. $\mathrm{J}$ Med $\mathrm{Pl}$. Res 4(3): 161-176.

17. Begum HA, Hamayun M, Zaman K, Hussain A \& Ruaf M (2015).
Phytochemical evaluation of ethnobotanically selected medicinal plants of Mardan, Pakistan. $J$ of $A d v$ Bot Zool 3(1): 1-5.

18. Ahmed I, \& Beg ZA (2001). Antimicrobial and phytochemical studies on 45 Indian medicinal plants against multi resistant human pathogens. J Ethono-Pharm 74(2):11323. 